\title{
EXPERIMENTAL LEVELLING AT THE INTERFACE OF OPTICAL ENVIRONMENTS
}

\author{
H. SIRU゚ČKOVÁ \\ Department of Special Geodesy, Faculty of Civil Engineering, Czech Technical University in Prague, \\ Thákurova 7, Praha 16629 \\ correspondence: hana.siruckova@fsv.cvut.cz
}

\begin{abstract}
The article discusses the problems of refraction and its impact on levelling at the interface of optical environments. It describes the influence of a vertical refraction and shows the results of investigating the effect of the refraction in the course of levelling at the interface of optical environments. The results of the experiment were obtained by levelling through the building of the National Technical Library in Prague Dejvice.
\end{abstract}

KEYWORDS: refraction, levelling, temperature gradient, digital thermometer.

\section{TERRESTRIAL REFRACTION}

Refraction is defined as the deflection of a light ray passing through an inhomogeneous medium. As a consequence, target $\mathrm{B}$ will be viewed by the observer in a tangential direction from the point of observation $\mathrm{A}$, as a generally curved spatial path of the ray, which is deviated from the direct line by refractive angle $\rho$. A simplified illustration is presented in Figure 1

Terrestrial refraction is caused by the passing of a light ray through the lowest layers of the atmosphere, known as the microclimate. The boundary of the microclimate has not yet been clearly determined. According to [4, this environment extends to a height of $2 \mathrm{~m}$ above the ground, while, according to [5], it extends to a height of $3 \mathrm{~m}$ above the ground. Most of geodetic measurements are performed in this very complex and time- varying optical medium. A light ray, on the path from the source to the receiver, penetrates from one environment in the atmosphere to another. According to Snell's Law of refraction, light is refracted when passing through the boundary of each environment and thus changes its original direction.

The sight line is tangential to the generally curved spatial path of the ray, deviating from the direct line by refraction angle $\rho$. In Geodesy, this can be divided in terms of the character of the measurable quantities into:

- the component affecting the measured horizontal directions - horizontal refraction;

- the component affecting the measured zenith angles - vertical refraction.

When applied to open spaces, the vertical refraction is generally considerably larger than the horizontal refraction. The temperature gradient is more distinctive in the vertical, than in the horizontal direction (caused by the arrangement of hot layers of air of varying temperature that are nearly parallel to the surface). However, under certain circumstances, the

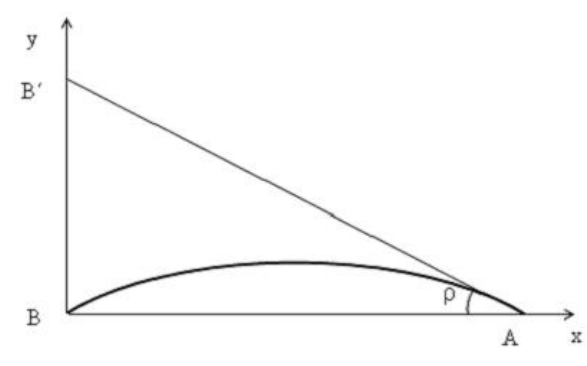

FiguRE 1. Refractive angle

refractive angle in the horizontal direction is greater than the one in the vertical direction. This is caused by the influence of the environment, e.g., measuring through a forest or a building. The influence of a building causes the temperature to vary more in the horizontal than in the vertical direction. The extent of the effect is different, depending on the type and colour of the surface - stone, plaster, glass (a white stucco, marble or glass surface will affect the measurement differently).

\section{VERTICAL REFRACTION}

The refraction of measured values will generally have the greatest effect in the vertical plane when measuring the zenith angles, and especially with the sight line extending close to the ground. In terms of the optical environmental properties, temperature and pressure conditions play the biggest role, as they affect density decisively, and hence the refractive index of atmospheric layers.

In the past, efforts were made to specify a universal refraction coefficient, the introduction of which would eliminate its effect from measurements. Under our conditions, the best known and most widely used average value of the refraction coefficient $k=0.1306$ was determined by Gauss between 1823 and 1826 from the adjustment of what is known as the Hanover arc measurements between Göttingen and Altona. In a 
free space fairly high above the ground [3] (regards at least $30 \mathrm{~m}$ above the ground as adequate measuring height), the temperature gradient is $0.01^{\circ} \mathrm{C} \mathrm{m}^{-1}$, which corresponds to the refraction coefficient of 0.14 . However, near the ground, the temperature gradient varies considerably, according to the intensity of solar radiation and the type of the surface over which the sight line passes.

Experiments in Slovakia are described in [8]. This article deals with trigonometric determination of heights with the sight lines of tens of meters to 300 meters, to reduce the influence of refraction, a refractory model from measured meteorological data is used. During the experiment the changes in temperature, humidity and barometric pressure of the air were measured. Trigonometric measurement was carried out in several places (Bratislava, Kleština, Haje and Gabčíkovo) and over several days and nights between the years 1975 and 2000. Observed items were monumented by drillings half a meter in thickness and from 6 to 10 meters of depth that are above the ground as pillars at the height of $1.3 \mathrm{~m}$ and $3 \mathrm{~m}$. The columns were fitted with the forced centering of instruments, respectively targets. Height difference between the points was determined twice with a high-precision levelling in the beginning and at the end of the experiment. The lengths between the points were measured by the electronic distance meters with empirical RMSE of up to $5 \mathrm{~mm}$. Zenith angles were measured with instruments Wild T3, Elta S10 and Geodimeter 600 . The measurements were organized in groups of 1-2 hour repetition. The changes in temperature, humidity and barometric pressure air were simultaneously measured.

The difference in the measurements on 8th and 9th of June 1976, between the height difference measured by precision levelling and trigonometrically calculated, gave the group average of -4.3 to $+3.3 \mathrm{~mm}$. In the case of adjusted group average, this deviation ranged from -2.8 to $+3.3 \mathrm{~mm}$.

Another way to determine the effect of vertical refraction is mentioned in 9]. The author describes the process of removing the influence of vertical refraction based on measurements of temperature, pressure and relative humidity. It also recommends the placement of multiple sensors for measuring of temperature, while the atmospheric pressure and humidity is sufficient to measure only in one place, because the pressure does not change significantly within a small locality and the humidity has only a negligible effect. The calculation should be done for each sight, in order to obtain several determining profiles for calculating the refractive index. If the target is out of the locality border, the profiles will be derived from the model.

Another article [10] summarizes mathematic methods for elimination of refraction using the measured values. A method of differential determination of the refractive index from the radio waves based on the relationship between gradients of temperature and humidity, a special equipment for automatic determining of the vertical refraction, refractometer studies in Antarctica and distance measurements from satellites are mentioned here.

\section{LEVELLing}

Unlike most systematic errors, the refractive effect cannot be excluded by geometric levelling from the centre. According to [2], a systematic refractive error can reach values of 0.05 to $0.1 \mathrm{~mm}$ per metre of height difference in levelling with $50 \mathrm{~m}$ sight lines and its size is directly proportional to the square of the length of the sight line.

In open space, air is warmed and cooled mainly from the ground, and therefore it can be presumed that, in the microclimate, atmospheric layers of the same temperature are approximately parallel to the ground surface.

Refraction during levelling and in the method of geometric levelling from the centre are generally manifested in an inclining terrain, because the sight line that is closer to the ground curves more and therefore the level of curvature is different when measured back and fore. This error is not excluded by geometric levelling from the centre; it is systematic in nature, known as differential refraction. When levelling on a ground which is practically horizontal, the influence of refraction, due to basically the same conditions along the entire length of the sight line, can be almost completely excluded by geometric levelling from the centre and therefore its influence is negligible.

In our case, the ground was almost horizontal, but not an open space. There was a significant change in temperature due to movement from the exterior of the building towards the interior. In addition, the temperature was balanced when opening the door. Therefore it can be assumed that there is a large variability of temperature gradients due to air flow.

The general rule for measurement at the interface of different optical environments (e.g., when entering a building, a mine, etc.) is that the levelling staff must always be at the interface. The reason is for the back and fore sights to pass through the same optical environment as long as possible. In our case, the opposite scenario was applied, with a levelling instrument situated at the interface. Thus, the back sight passes through a completely different optical environment than the fore sight. It was an effort to find how non- compliance with the "levelling staff stands at the interface" principle would affect the measurement in extreme cases.

\section{ExPERIMENTAl LEVELling THROUGH THE BUILDING of the National TeChNiCAL Library in Prague DeJVice}

Measurements were carried out in the National Technical Library and surroundings in Prague Dejvice. The 


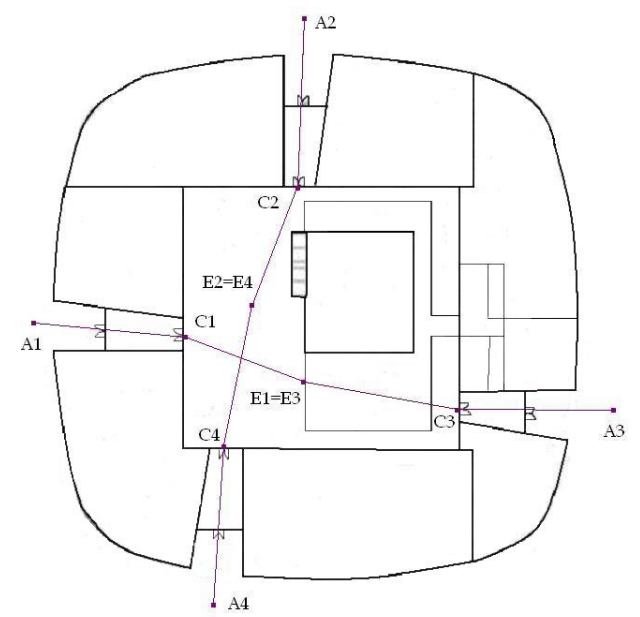

Figure 2. Layout of the Library and configuration of individual levelling points

building of the National Technical Library seemed exceptionally appropriate for the experiment, because it is detached and accessible from all sides, making it possible to build up a closed levelling line around it. Moreover, the approximate shape of the building is a super-ellipse (a more detailed study of the shape and properties of the Library building [6]) depicts entrances on all four sides and a large atrium in the interior, through which the levelling lines can be led between all the entrances. The layout of the Library is depicted in Fig. 2

The experiment was carried out every Sunday in order to avoid excessive movement of persons through individual entrances. On Sundays, only the 24-hour study room via entrance No. 3 is open. The rest of the entrances are locked.

The author would like to express his gratitude to the Library management for the unlocking of the entrances, thus enabling the execution of the entire experiment.

\section{INSTRUMENTS}

\subsection{Temperature MeASUREMENT}

The temperatures were measured with the digital thermometer BTM-42083D equipped with 12 temperature sensors. When measuring on 3rd November 2013 all 12 sensors were functional. From 1st December 2013 only 7 sensors have been functional. For the temperature measurement, a one minute interval was set.

\subsection{LEVELLING INSTRUMENTS}

The measurements were carried out with the levelling instrument Koni 007, serial number 150972. Throughout the experiment, the 1.8 meters long staff no. 49356 was used. The tripod Weiss was used during the measurements.

The second leveling instrument was a digital DNA 03 serial number 337893, art number 723289 .
Throughout the experiment, the staff with serial number 35713 and the Leica tripod was used.

Identical levelling staffs and devices were used for all measurements.

\subsection{InSTRUMENT CALIBRATION}

The staff used to levelling instrument Koni 007 was calibrated and the measuring in the laboratory revealed that the scale of the staff is 0.999999 .

The calibration DNA 03 found the following values:

\begin{tabular}{ccc}
\hline & System scale & System scale RMS \\
\hline 1 & $+17 \mathrm{ppm}$ & $3 \mathrm{ppm}$ \\
2 & $+17 \mathrm{ppm}$ & $1 \mathrm{ppm}$ \\
3 & $+14 \mathrm{ppm}$ & $2 \mathrm{ppm}$ \\
\hline
\end{tabular}

\subsection{Calibration of temperature sensors}

Temperature sensors were immersed in water to eliminate short-term environmental influences, and were all in the same condition. Measurements were conducted for approximately 1 hour, with temperatures reading every minute. A mean was computed from the values thus measured. One sensor was taken as fixed and corrections for the other sensors were calculated from it.

\section{WEATHER}

On 3rd November 2013, the weather was mostly rainy. It rained in the morning and around midday it only drizzled. Throughout the day it was windy and cloudy. Humidity ranged from $46 \%$ to $49 \%$, the pressure ranged from 971 mbar to 973 mbar. Temperatures ranged from $20^{\circ} \mathrm{C}$ to $24^{\circ} \mathrm{C}$ inside the building and outside from $9{ }^{\circ} \mathrm{C}$ to $13{ }^{\circ} \mathrm{C}$ outside the building.

On 1st December 2013, it was cloudy all day without rain and without sunshine. There were no significant changes in the weather. Humidity ranged from $29 \%$ to $33 \%$, the pressure was 994 mbar. Temperatures ranged from $18^{\circ} \mathrm{C}$ to $19^{\circ} \mathrm{C}$ inside the building and from $7^{\circ} \mathrm{C}$ to $9^{\circ} \mathrm{C}$ outside the building.

On 9th February 2014, the weather was similar to the weather as on 1st December 2013. It was cloudy, with no wind and no significant changes in the weather. Humidity ranged from $25 \%$ to $30 \%$ and the pressure was 969 mbar. Temperatures ranged from $17^{\circ} \mathrm{C}$ to $19^{\circ} \mathrm{C}$ inside the building and from $4{ }^{\circ} \mathrm{C}$ to $7^{\circ} \mathrm{C}$ outside the building.

On 6th April 2014, in the morning, it was overcast, cloudy. At midday, the sun began to shine and in the afternoon the skies were already clear. Humidity was $35 \%$ and the pressure of 985 mbar. The temperature ranged from $19^{\circ} \mathrm{C}$ to $21^{\circ} \mathrm{C}$ inside the building and from $14^{\circ} \mathrm{C}$ to $18^{\circ} \mathrm{C}$ outside the building.

On 27 th July 2014 the weather was sunny all day. The skies were completely clear and the sunshine was very strong. When measuring, the sun was shining on the entrance no.1 all the time and it was windy, 


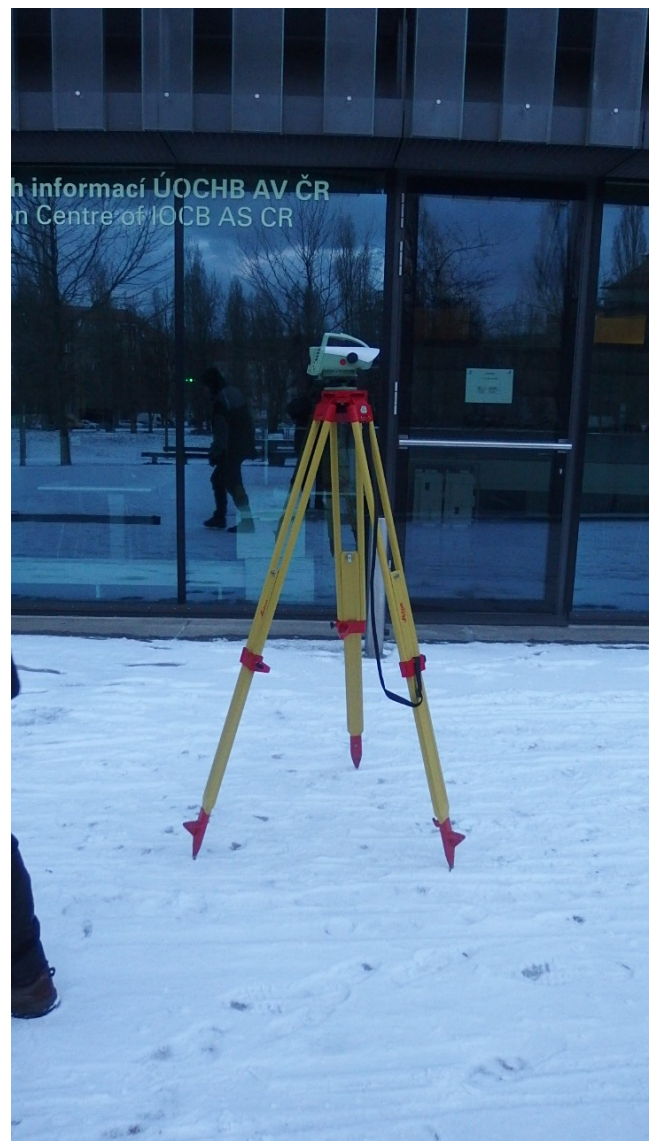

FigURE 3. DNA 03 levelling instrument; measurement on 8 February 2015

entrance no. 2 was in the half-shade, entrance no.3 was in the shade all day and when measuring the entrance no. 4 , it was sunny and slightly windy. Humidity was $53 \%$ and the pressure of 984 mbar. Indoor temperature ranged from $24^{\circ} \mathrm{C}$ to $27^{\circ} \mathrm{C}$, the outside temperature ranged from $29^{\circ} \mathrm{C}$ to $33^{\circ} \mathrm{C}$.

On 8th February 2015 the weather was changeable. When measuring the entrance no. 4 , the sun was shining, the entrances no. 2 and no. 3 were in the shade and when entrance no. 1 was measured, it was snowing and wind gusts with snow occurred. Humidity was $20 \%$ and the pressure of 987 mbar. Indoor temperature ranged from $17^{\circ} \mathrm{C}$ to $22^{\circ} \mathrm{C}$ and the outside temperature ranged from $1^{\circ} \mathrm{C}$ to $3^{\circ} \mathrm{C}$.

\section{DESCRIPTION OF THE EXPERIMENT}

The aim of the experiment is to determine the difference between the height difference of points identified by the measuring of levelling lines conducted through the building and the levelling lines conducted around the building. The total number of levelling lines around the building was 11, 6 of which were measured with the leveling instrument Koni 007 and 5 with the digital leveling instrument DNA 03. These levelling lines were measured in different seasons and times of the day and in different weather conditions. From these measurements, the average was computed

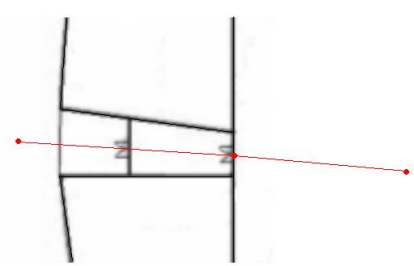

FiguRE 4. Measurement at individual entrances

and from this average the height differences between the points were calculated. It is assumed that the resulting height differences, due to a greater number of repeated measurements, are the real values.

These values are compared with various levelling lines conducted throughout the building. In addition to measurement errors, the refraction influences are taken into account, regarding the polygons conducted through the building. Further, the temperatures along the sight line are measured and the temperature gradients are calculated. From the temperature gradients determined this way, the estimated errors from the effect of refraction are calculated. By comparing the differences between the height difference determined from the levelling lines measured around the building and the levelling lines measured through the building, with the calculated errors from the influence of refraction, firstly, the correct use of formulas can be verified and secondly any mistake in measurement, which can happen in an extreme case when the instrument stands on the optical environment interface and not a staff, can be detected.

A screw in a metal plug was placed in a concrete fissure and monumented in front of each entrance outside the building. It was not moved during the entire course of the experiment (from November 2013 to February 2015). See the building layout - Fig. 2 points A1-A4. Only one point was moved (between measurements in December 2013 and February 2014), probably due to mechanical snow removal.

Nuts with spherical caps were placed within the building, fixed to the floor with double-sided adhesive tape. These nuts were placed in position in the morning at the beginning of measurement and always removed at the end of the day. A total of 6 such nuts were positioned, 4 of which were between the internal doors of the building and 2 in the centre of the atrium. There was always one shared point for entrances 1 and 3 and for entrances 2 and 4 . See the building layout - Fig 2, points C1-C4 and E1-E4.

Measurements were carried out separately for each entrance. Temperature sensors were positioned, the levelling set was measured between the exterior point and a point in the centre of the atrium. The entire apparatus was moved to another entrance. The measuring procedure was: the levelling instrument was 


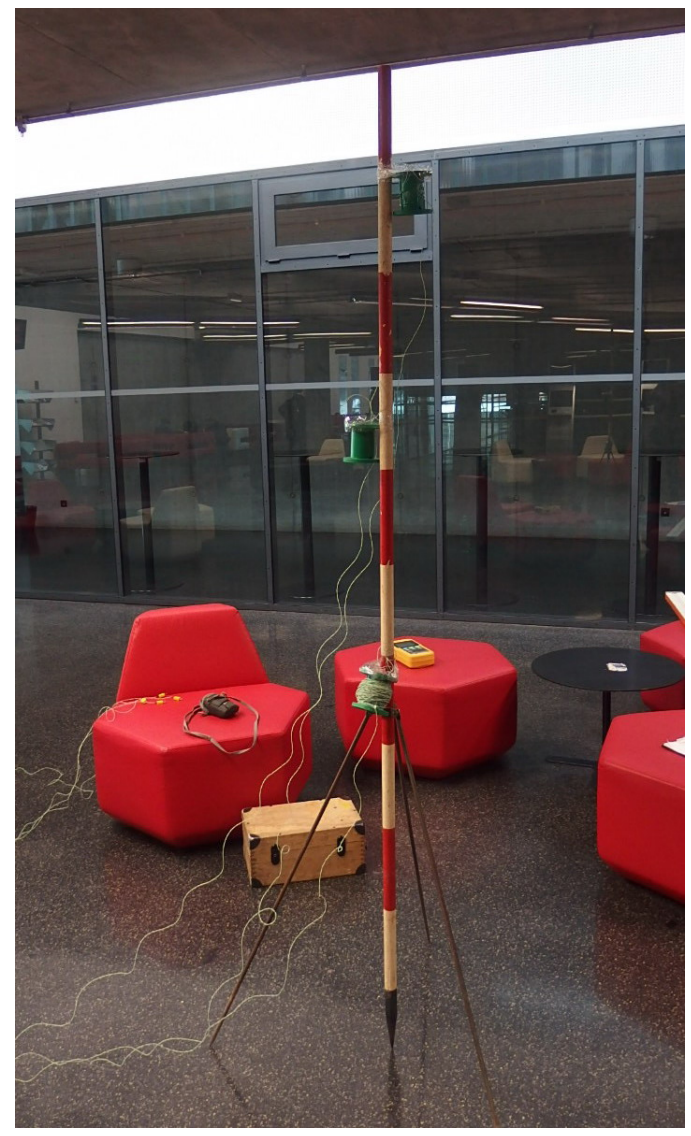

FIGURE 5. Fixing of temperature sensors at the range pole

positioned at the interior doors of the building and sight lines led to a permanently monumented point in front of the building and to the point in the centre of the building for a given levelling line. The layout of the measurement in one entrance is shown in Fig. 4

Sight lines were approx. $20 \mathrm{~m}$ long. The entire levelling line from a permanently monumented point in front of the building through the building and the permanently monumented point on the other side of the building was divided into 2 sets.

Arrangement of temperature sensors. 7 functioning temperature sensors were fixed on 3 range poles along the sight lines. Sensors on one range pole were at heights of $1 \mathrm{~m}, 1.5 \mathrm{~m}$ and $2 \mathrm{~m}$ above the ground. The attachment can be seen in Fig. 5 Two range poles had sensors at heights of $1 \mathrm{~m}$ and $2 \mathrm{~m}$ above the ground. The temperature gradient was calculated from temperatures measured by these sensors at different heights.

Arrangement of the range poles. The range pole with 3 temperature sensors was placed outsidethe building. One range pole with 2 temperature sensors was positioned between the exterior and interior doors of the building and the last range pole with 2 temperature sensors was positioned inside the building.

After completing the measurement in each entrance, the temperature sensors were moved to another en-

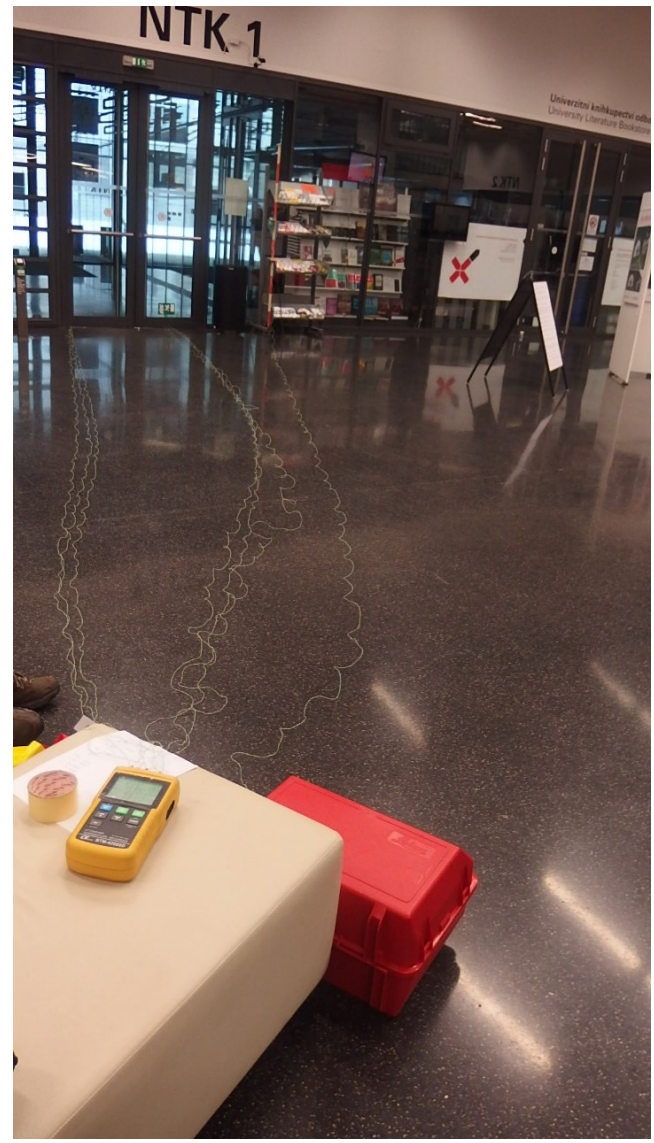

Figure 6 . The positioning of temperature sensors at entrance No. 1

trance. The position of the temperature sensors at entrance No. 1 is shown in Fig. 6

\section{Formulas USED}

Calculation of correction of $d L$ according to [7]:

$$
\begin{gathered}
d L=\frac{1}{2} \Gamma s^{2}\left(1-t g^{-1} \beta . t g^{-1} z\right) \frac{d t}{d h^{\prime}}, \\
\Gamma=0.000294 \frac{p}{760} \cdot \frac{0.00367}{1+0.00367 t},
\end{gathered}
$$

where $s(\mathrm{~m})$ is the sight line length; $\beta$ is the zenith angle of atmospheric layers; $z$ is the zenith angle of sight line; $\frac{d t}{d h}\left({ }^{\circ} \mathrm{C} \mathrm{m}^{-1}\right)$ is the temperature gradient; $p$ (torr) is the atmospheric pressure; $t\left({ }^{\circ} \mathrm{C}\right)$ is the temperature in ${ }^{\circ} \mathrm{C}$.

For levelling $z=100 \mathrm{~g}$ the formula is simplified:

$$
d L=\frac{1}{2} \Gamma s^{2} \frac{d t}{d h}
$$

Permissible deviation of measurement was calculated according to [1]: Lengths of levelling lines around the building: $300 \mathrm{~m}$, through the building: $84 \mathrm{~m}$;

$$
\Delta_{m m}=\sqrt[3]{R_{k m}}
$$

For levelling line around the building: $\Delta_{\max , \operatorname{mm}}=$ $1.64 \mathrm{~mm}$ For levelling line through the building: $\Delta_{\max , m m}=0.87 \mathrm{~mm}$ 


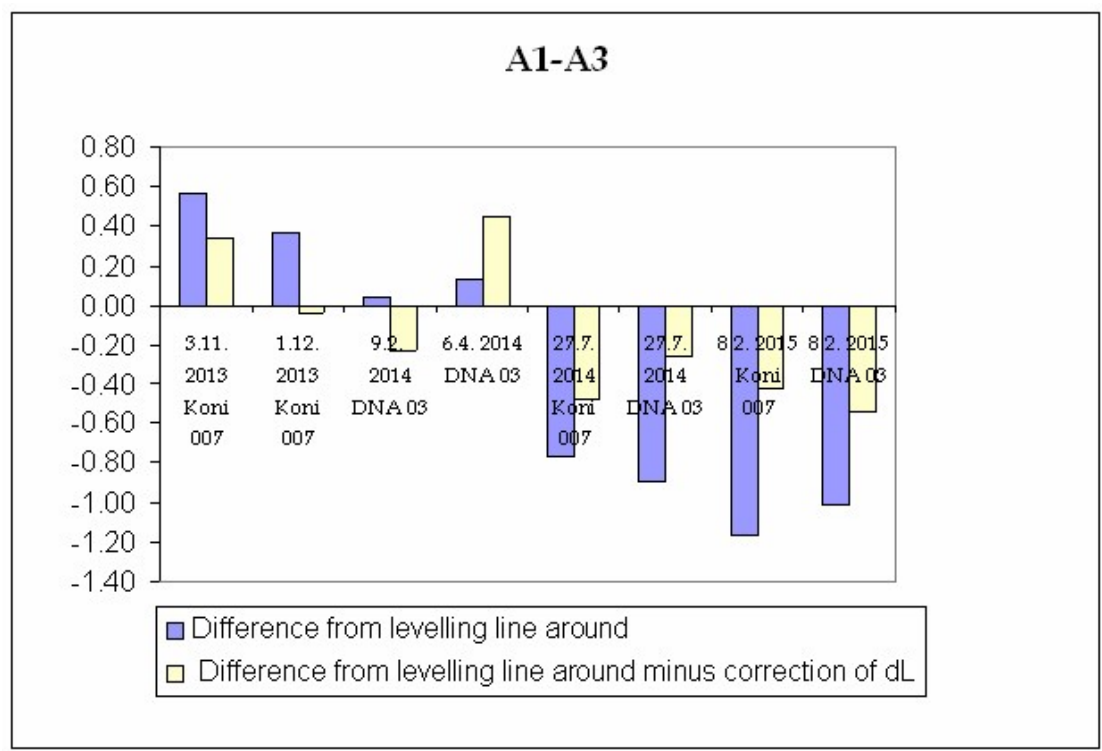

FIGURE 7.

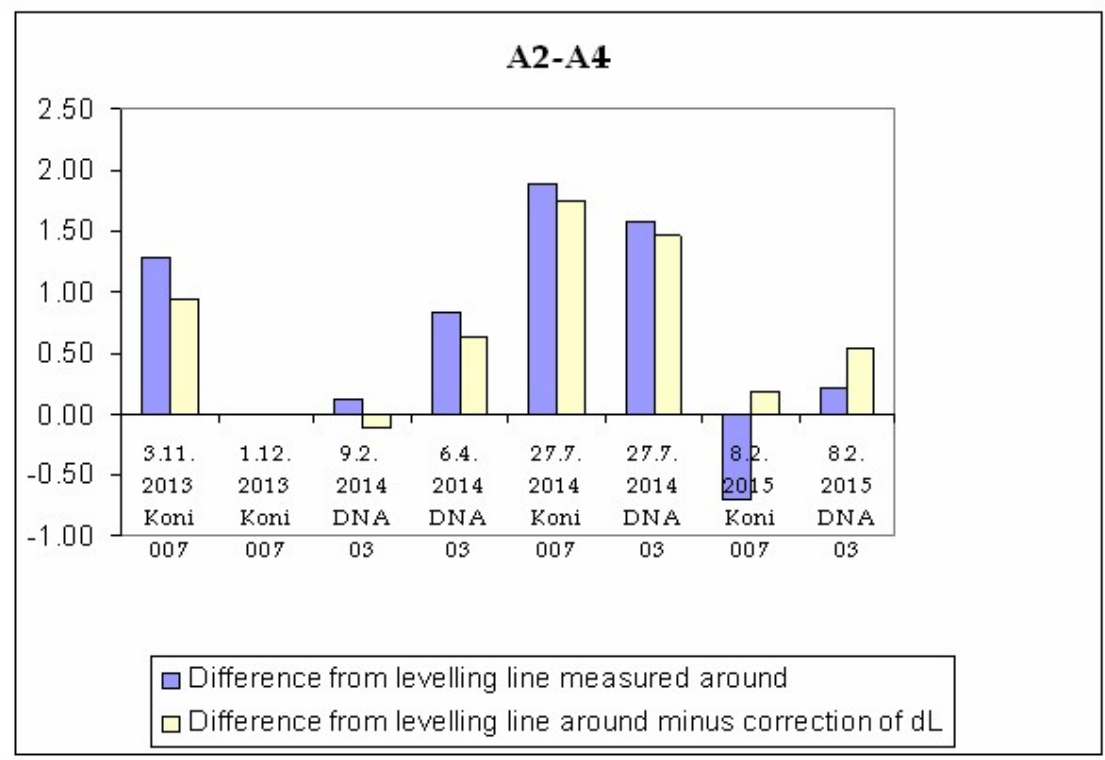

FIGURE 8.

\section{Results}

Closed levelling line around the Library. Point A2 basic referential elevation $0 \mathrm{~mm}$. Due to movement of point A4, measurements of the levelling lines were divided into 2 sections. The first is derived from the measurement on 3 November and 1 December 2013, the second is from 1 August 2014 to 13 February 2015.

In all cases of the measurement of the levelling line around the Library, measurement accuracy fulfilled the limits for precise levelling, no standard deviations were exceeded.

Closures of levelling lines around the Library

The height differences of points A1-A3 and A2-A4 calculated from average values are stated in Tables 1 and 2

The height differences between points A1-A3 and
A2-A4 were calculated from levelling lines led through the building. This difference found from the levelling line measured around the building and through it, and the correction of $\mathrm{dL}$ were calculated according to the above-mentioned formula.

The values from Tables 5 and 6 are displayed in Figures 7 and 8 These charts clearly show that the introduction of corrections to the height differences measured through the building approached the averaged height difference measured around the building. It can be supposed that the assumption of the experiment was verified and that the results gained by the introduction of corrections calculated from temperature gradients are improved in most cases.

Table 7 shows the gradient values outside the building at the individual entrances. These values are displayed in Figure 9 


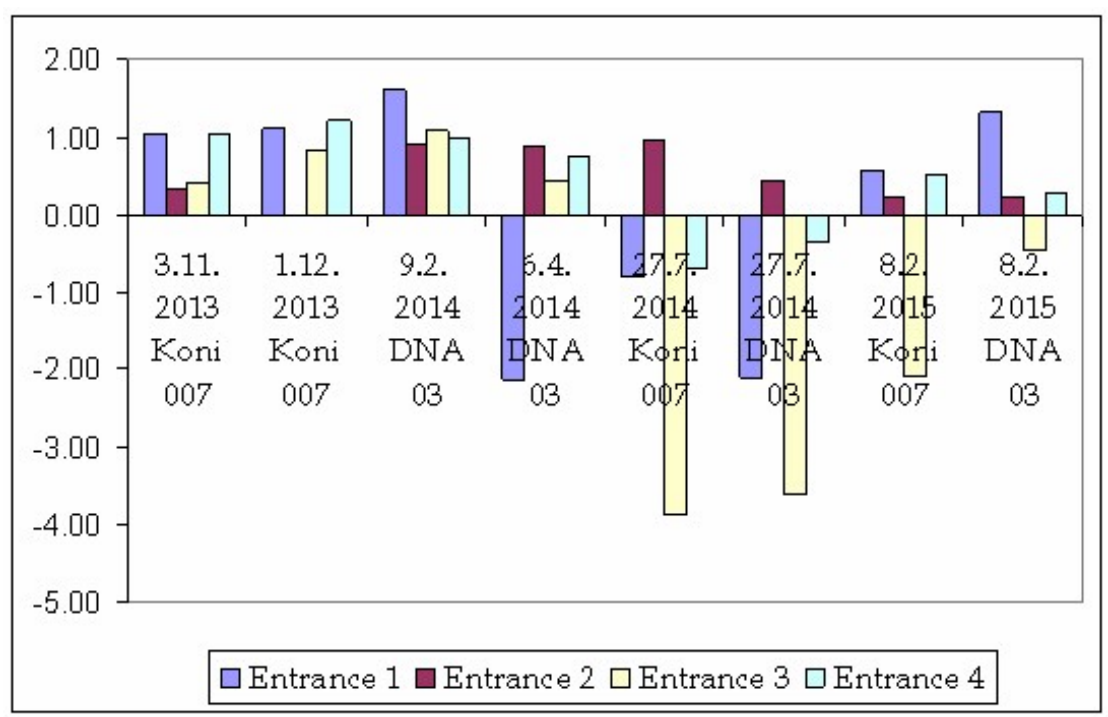

Figure 9.

\begin{tabular}{rccc}
\hline \multicolumn{1}{c}{ Date } & $\mathrm{A} 1(\mathrm{~mm})$ & $\mathrm{A} 4(\mathrm{~mm})$ & $\mathrm{A} 3(\mathrm{~mm})$ \\
\hline 3 November 2013 Koni 007 & 7.55 & -34.10 & 28.25 \\
3 November 2013 Koni 007 & 7.60 & -34.50 & 28.65 \\
1 December 2013 Koni 007 & 7.95 & -34.10 & 28.15 \\
1 December 2013 Koni 007 & 7.75 & -33.75 & 28.35 \\
\hline Mean & 7.71 & -34.11 & 28.36 \\
Standard error of mean & 0.09 & 0.15 & 0.10 \\
\hline
\end{tabular}

TABLE 1.

\begin{tabular}{rccc}
\hline \multicolumn{1}{c}{ Date } & A1 $(\mathrm{mm})$ & A4 $(\mathrm{mm})$ & A3 $(\mathrm{mm})$ \\
\hline 1 August 2014 Koni 007 & 7.70 & -32.25 & 28.30 \\
13 February 2015 Koni 007 & 7.95 & -32.50 & 28.15 \\
9 February 2014 DNA03 & 8.14 & -32.47 & 28.66 \\
9 February 2014 DNA03 & 8.16 & -32.34 & 28.69 \\
6 April 2014 DNA03 & 7.73 & -32.59 & 28.63 \\
27 July 2014 DNA03 & 7.62 & -32.49 & 28.65 \\
8 February 2015 DNA03 & 7.49 & -32.93 & 28.84 \\
\hline Mean & 7.83 & -32.51 & 28.56 \\
Standard error of mean & 0.10 & 0.08 & 0.09 \\
\hline
\end{tabular}

TABLe 2.

\begin{tabular}{rc}
\hline Koni 007 & Polygon closure $(\mathrm{mm})$ \\
\hline 3 November 2013 & 0.275 \\
3 November 2013 & -0.4 \\
1 December 2013 & -0.025 \\
1 December 2013 & -0.075 \\
1 August 2014 & 0.25 \\
13 February 2015 & 0.25 \\
\hline
\end{tabular}

\begin{tabular}{rc}
\hline DNA 03 & Polygon closure $(\mathrm{mm})$ \\
\hline 9 February 2014 & 0.14 \\
9 February 2014 & 0.13 \\
6 April 2014 & -0.205 \\
27 July 2014 & 0.19 \\
8 February 2015 & 0.265 \\
\hline
\end{tabular}

TABle 3.

\begin{tabular}{rcc}
\hline & $\mathrm{A} 1-\mathrm{A} 3(\mathrm{~mm})$ & $\mathrm{A} 2-\mathrm{A} 4(\mathrm{~mm})$ \\
\hline By Feb 2014 & 20.87 & -34.11 \\
From Feb 2014 & 20.73 & -32.51 \\
\hline
\end{tabular}

TABLE 4. 


\begin{tabular}{ccccc}
\hline & & $\begin{array}{c}\text { Difference from } \\
\text { levelling line } \\
\text { Date }\end{array}$ & A1-A3 $(\mathrm{mm})$ & $\begin{array}{c}\text { Difference from levelling } \\
\text { line around minus } \\
\text { correction of } d L(\mathrm{~mm})\end{array}$ \\
\hline 3 November 2013 Koni 007 & 20.30 & 0.57 & 0.23 & 0.34 \\
1 December 2013 Koni 007 & 20.50 & 0.37 & 0.41 & -0.04 \\
27 July 2014 Koni 007 & 21.50 & -0.77 & -0.28 & -0.49 \\
8 February 2015 Koni 007 & 21.90 & -1.17 & -0.74 & -0.43 \\
9 February 2014 DNA 03 & 20.69 & 0.04 & 0.27 & -0.23 \\
6 April 2014 DNA 03 & 20.60 & 0.13 & -0.31 & -0.44 \\
27 July 2014 DNA 03 & 21.63 & -0.89 & -0.63 & -0.55 \\
8 February 2015 DNA 03 & 21.75 & -1.02 & -0.47 & -26 \\
\hline
\end{tabular}

TABle 5.

\begin{tabular}{|c|c|c|c|c|}
\hline Date & $\mathrm{A} 2-\mathrm{A} 4(\mathrm{~mm})$ & $\begin{array}{l}\text { Difference from } \\
\text { levelling line } \\
\text { measured } \\
\text { around }(\mathrm{mm})\end{array}$ & $d L(\mathrm{~mm})$ & $\begin{array}{c}\text { Difference from levelling } \\
\text { line measured around - } \\
\text { correction of } d L(\mathrm{~mm})\end{array}$ \\
\hline 3 November 2013 Koni 007 & -35.40 & 1.29 & 0.34 & 0.95 \\
\hline 1 December 2013 Koni 007 & \multicolumn{4}{|c|}{ not measured } \\
\hline 27 July 2014 Koni 007 & -35.90 & 1.89 & 0.15 & 1.74 \\
\hline 8 February 2015 Koni 007 & -31.80 & -0.71 & -0.89 & 0.18 \\
\hline 9 February 2014 DNA 03 & -32.64 & 0.13 & 0.23 & -0.1 \\
\hline 6 April 2014 DNA 03 & -33.35 & 0.84 & 0.20 & 0.64 \\
\hline 27 July 2014 DNA 03 & -35.59 & 1.58 & 0.12 & 1.46 \\
\hline 8 February 2015 DNA 03 & -32.72 & 0.21 & -0.33 & 0.54 \\
\hline
\end{tabular}

TABLe 6.

\begin{tabular}{rcccc}
\hline Date & $\begin{array}{c}\text { Entrance 1 } \\
\left({ }^{\circ} \mathrm{C} \mathrm{m}^{-1}\right)\end{array}$ & $\begin{array}{c}\text { Entrance 2 } \\
\left({ }^{\circ} \mathrm{C} \mathrm{m}^{-1}\right)\end{array}$ & $\begin{array}{c}\text { Entrance 3 } \\
\left({ }^{\circ} \mathrm{C} \mathrm{m}^{-1}\right)\end{array}$ & $\begin{array}{c}\text { Entrance 4 } \\
\left({ }^{\circ} \mathrm{C} \mathrm{m}^{-1}\right)\end{array}$ \\
\hline 3.11. 2013 Koni 007 & 1.04 & 0.33 & 0.41 & 1.04 \\
1.12. 2013 Koni 007 & 1.11 & & 0.29 & 1.20 \\
9.2. 2014 DNA 03 & 1.59 & 0.92 & 1.57 & 1.00 \\
6.4. 2014 DNA 03 & -2.13 & 0.89 & 0.45 & 0.77 \\
27.7. 2014 Koni 007 & -0.79 & 0.97 & -2.07 & -0.70 \\
27.7. 2014 DNA 03 & -2.08 & 0.45 & -3.73 & -0.34 \\
8.2. 2015 Koni 007 & 0.57 & 0.22 & -0.38 & 0.53 \\
8.2. 2015 DNA 03 & 1.33 & 0.23 & -0.59 & 0.29 \\
\hline
\end{tabular}

TABLE 7.

\section{Conclusion}

Differences between mean of levelling lines measured around the Library and of individual levelling lines through the building range from $-1.17 \mathrm{~mm}$ to $1.89 \mathrm{~mm}$.

The permissible deviation for respective length of levelling line is $0.87 \mathrm{~mm}$. Therefore, it was exceeded several times. The effect of refractive error, calculated according to formulas, approximates the differences between the levelling lines measured around the Library and through the building. Correction of the levelling lines measured through the building with the calculated error of refraction, in most cases, would lead to results significantly similar to the results obtained by levelling around the building.
Exceptions are the measurements of 27 July 2014; differences between points A2-A4 are $1.58 \mathrm{~mm}$ with the DNA 03 instrument and $1.89 \mathrm{~mm}$ with the Koni 007. However, the correction of the influence of refraction calculated from temperature gradients is only slight. Therefore, it is probable that there was an erroneous measurement at point A4.

Further differences were identified using the DNA 03 instrument in levelling line A1-A2 on 9 February 2014 and in levelling line A2-A4 on 6 April 2014 and 8 February 2015 when, with the implementation of correction, there would have been a greater deviation from the values obtained by levelling around the building. In two cases, the values are even opposite. This could be caused by short-term fluctuations in the 
environment that were not recorded by the sensors, or the simple fact that the values are on the border of measurement accuracy.

In order to identify any significant systematic error during measurement, whether of the instrument or of the sensor during reading, measurement was carried out with two instruments - the optical-mechanical Koni 007 and digital DNA 03. After comparing the measured results, it can be stated that no serious errors were manifested, nor any errors in the accuracy of the reading with the Koni 007. The sizes of standard errors and calculated deviations are comparable for both instruments.

\section{REFERENCES}

[1] Blažek R, Skořepa Z (1999). Geodézie 30. Výškopis, Prague, CTU, ISBN 80-01-01598-X

[2] Hradilek L (1984). Vysokohorská geodézie. Prague, Academia

[3] Hauf M et al.(1989). Geodézie - Technický průvodce 42. Prague, SNTL, ISBN 80-03-00142-0

[4] Pospíšil J (1980). Vliv atmosféry na šíření laserového záření při metodě záměrné přímky, Geodetický a
Kartografický obzor 26(68), No. 1, pp. 9-14. ISSN 0016-7096

[5] Vyskočil P (1966). Studium možností snížení vlivu mikroklimatu na nivelační měření, candidate dissertation work. Prague, CTU in Prague

[6] Dušek R, Skořepa Z (2012). Národní technická knihovna z pohledu superelipsy, Geodetický a kartografický obzor, year 58/100, No. 3, pp. 45-50. ISSN 0016-7096

[7] Vyskočil P (1982). Refraction in levelling, collection of VÚGTK research works, volume 14

[8] Sokol Š., Ježko J.: Možnosti eliminácie vplyvu refrakcie na trigonometrické meranie výšok, Acta Montanistica Slovana, year 10 (2005), No. 2, pp. 218-227. ISSN 1335-1788

[9] Urban R., Štroner M.: Modeling of the influence of vertical refraction on the precise geodetic measurements based on discrete measurement of atmospheric parameters. In: QUAERE 2013. Hradec Králové: Magnanimitas, 2013, vol. 1, art. no. 1, p. 2624-2631.

[10] Ostrovskij, A. L.: Dostiženija I zadači refraktometrii. Lvov: Geoprof 1/2008, Lvovskaja Politechnika, pp.6-15. ISSN 2306-8736 